Wkład autorów: A Projekt badania

B Gromadzenie danych

Analiza danych

Interpretacja danych

Przygotowanie pracy

F Przegląd literatury

G Gromadzenie funduszy

\section{Podstawy teoretyczne tworzenia i walidacji narzędzi ankietowych na przykładzie kwestionariusza LittlEARS}

\section{Theoretical basis for the preparation and validation of questionnaire tools, as applied in the LittIEARS questionnaire}

\author{
Anita Obrycka ${ }^{\mathrm{ADEF}}$, Artur Lorens ${ }^{\mathrm{DF}}$ \\ Instytut Fizjologii i Patologii Słuchu, Światowe Centrum Słuchu, Zakład Implantów \\ i Percepcji Słuchowej, Warszawa/Kajetany
}

\title{
Streszczenie
}

W pracy przedstawiono podstawy teoretyczne tworzenia i walidacji narzędzi ankietowych. Najważniejsze etapy tego procesu: zdefiniowanie badanego problemu, przygotowanie pozycji testowych, określenie formatu odpowiedzi, standaryzacja, walidacja i normalizacja zostały omówione na przykładzie kwestionariusza LittlEARS.

Słowa kluczowe: kwestionariusze • tworzenie kwestionariuszy • walidacja kwestionariuszy

\section{Abstract}

The following paper presents theoretical basis for the preparation and validation of questionnaire tools. Based on the LittlEARS questionnaire, key stages of this process are discussed, including: defining the research problem, preparing of test items, specifying the response format, standardising, validating and normalising the test.

Key words: questionnaires $\bullet$ questionnaire preparation • questionnaires validation

\section{Wstęp}

Zadawanie pytań jest szeroko akceptowaną, niekosztowną, a czasem jedyną metodą gromadzenia informacji o zachowaniach, doświadczeniach, działaniach, motywach, poglądach, wartościach i postawach. Różnego rodzaju kwestionariusze, ankiety, skale, wywiady są powszechnie wykorzystywane w badaniach socjologicznych, psychologicznych, badaniach opinii publicznej, badaniach rynku, szkolnictwie, a także w medycynie.

Rosnące zapotrzebowanie na różnego rodzaju testy (kwestionariusze, ankiety, skale, wywiady) zrodziło konieczność wypracowania standardów zapewniających wysoką jakość diagnostyczną powstających narzędzi. W tym celu w 1978 r. powstała Międzynarodowa Komisja ds. Testów - ITC (ang. International Test Commission). ITC jest towarzystwem naukowym zrzeszającym komisje ds. testów z różnych krajów, towarzystwa psychologiczne, wydawców i dystrybutorów testów. Zarówno ITC, jak i organizacje takie jak American Educational Research Association, American Psychological Assocation, National Council on Measurement in Education zajmują się propagowaniem efektywnego stosowania testów i kwestionariuszy zapewniających diagnostykę na najwyższym poziomie, upowszechnianiem dobrej praktyki w zakresie tworzenia nowych testów i adaptacji istniejących oraz edukacją odnoszącą się do właściwego i etycznego stosowania testów. Jedynie kwestionariusze przygotowane i stosowane zgodnie $\mathrm{z}$ najnowszymi standardami i wytycznymi dotyczącymi opracowania i stosowania testów posiadają wysoką wartość diagnostyczną [1-4].

Coraz częściej kwestionariusze wykorzystywane są również w audiologii do oceny skuteczności nowych technologii medycznych, pozwalając na poszerzenie oceny 
pacjenta o aspekty związane z subiektywną oceną efektów leczniczo-rehabilitacyjnych czy poprawą jakości życia [5-8]. W przypadku małych dzieci z niedosłuchem w okresie pierwszych lat życia zastosowanie odpowiednio przygotowanych kwestionariuszy pozwala na poszerzenie oceny skuteczności interwencji o badanie rozwoju słuchowego dziecka oraz jego zdolności w zakresie percepcji mowy [9-11]. Zastosowanie $\mathrm{w}$ tej grupie pacjentów tylko badań audiologicznych dostosowanych do wieku pozwala jedynie na uzyskanie informacji o możliwości stymulacji akustycznej drogi słuchowej.

Do badań związanych z oceną skuteczności technologii medycznych poszukuje się kwestionariuszy uniwersalnych kulturowo, dostępnych w wielu językach, tak aby możliwe było prowadzenie międzyośrodkowych badań według wspólnego protokołu [12]. Takie rozwiązanie pozwala na zwiększenie liczebności badanej grupy, powodując wzrost wiarygodności i istotności klinicznej prowadzonych badań. Przy wyborze narzędzia bierze się również pod uwagę możliwość porównania uzyskanych wyników badań do normy dla danej populacji. Wyznaczenie wartości normatywnych dla badania danym kwestionariuszem jest zatem jego dodatkowym atutem.

Przykładem jednego z nielicznych kwestionariuszy stosowanych w audiologii, przeznaczonych dla dzieci w pierwszych latach życia, przygotowanego zgodnie z aktualnymi standardami, zwalidowanego, dostępnego w ponad 20 językach, pozwalającego na odniesienie uzyskanych wyników do wartości uzyskiwanych przez dzieci ze słuchem prawidłowym jest kwestionariusz LittlEARS [13-17]. W ostatecznej wersji zawiera 35 pytań, na które rodzice odpowiadają, wybierając jedną z dwóch odpowiedzi: „tak” lub „nie”. Większość pytań została uzupełniona przykładami. Pytania uporządkowane są zgodnie z kolejnymi etapami rozwoju słuchowego dziecka. Łączny wynik badania kwestionariuszem LittlEARS jest sumą wszystkich odpowiedzi „tak”. Uzyskany wynik porównywany jest z wartością oczekiwaną - zależną od wieku średnią uzyskiwaną przez dzieci ze słuchem prawidłowym, i z wartością minimalną, oznaczającą, że wyniki $95 \%$ dzieci z próby objętej walidacją znajdowały się powyżej tych wartości, a wartości poniżej tej granicy są mało prawdopodobne $(<5 \%)$ w danej grupie wiekowej. Osiągnięcie łącznego wyniku LittlEARS poniżej wartości minimalnej może wskazywać na nieprawidłowy rozwój słuchowy.

\section{Cel}

Celem pracy było przedstawienie podstaw teoretycznych tworzenia i walidacji narzędzi ankietowych na przykładzie kwestionariusza LittlEARS.

\section{Tworzenie kwestionariuszy}

Aby nowy kwestionariusz stał się narzędziem diagnostycznym, muszą być przeprowadzone określone działania, począwszy od właściwego zdefiniowania badanego proble$\mathrm{mu}$, poprzez przygotowanie pozycji testowych (pytań lub stwierdzeń), określenie formatu odpowiedzi, opracowanie procedury testowej (standaryzacja), a skończywszy na przeprowadzeniu procesu jego walidacji i normalizacji.
Właściwe zdefiniowanie problemu badawczego, oparte na teoretycznych podstawach jest zagadnieniem kluczowym przy konstruowaniu nowego narzędzia. Przy tworzeniu kwestionariusza badacz musi sprecyzować, jakiego rodzaju informacje o badanym potrzebuje uzyskać, musi się upewnić, że badany posiada wymagane informacje oraz że ma dostęp do tych informacji w warunkach badania $[18,19]$.

Celem autorów kwestionariusza LittlEARS było skonstruowanie narzędzia pozwalającego na ocenę rozwoju słuchowego dziecka w okresie przedsłownym $[13,20]$. Podstawę teoretyczną do opracowania pytań kwestionariusza stanowiły zidentyfikowane i opisane w literaturze etapy rozwoju słuchowego dziecka w pierwszych latach życia [21-24]. Rzetelnym źródłem informacji o zachowaniach słuchowych dziecka są jego rodzice lub opiekunowie, którzy mają możliwość obserwowania dziecka w warunkach życia codziennego, dlatego też adresatem pytań kwestionariusza LittlEARS są rodzice lub opiekunowie badanych dzieci [25].

Pozycje kwestionariusza w formie pytań lub stwierdzeń powinny być przygotowane na podstawie wiedzy teoretycznej dotyczącej badanego zagadnienia. Przygotowując pytania, należy kierować się opisanymi w literaturze zasadami, pozwalającymi na zminimalizowanie błędów związanych $\mathrm{z}$ ich interpretacją przez badanego. Do głównych zasad, którymi należy kierować się przy przygotowaniu pozycji testowych, należą: użycie prostego słownictwa, unikanie słów abstrakcyjnych, nie do końca zdefiniowanych (np. polityka) lub wieloznacznych, slangu, słów określających częstość, oceniających, moralizujących. Nie należy używać zaprzeczeń, nazw instytucji, nazwisk. Pozycje kwestionariusza nie powinny dotyczyć zagadnień zbyt ogólnych - wymiar, którego dotyczą, musi być jasno sprecyzowany. Nie powinny być zbyt długie - najlepiej mniej niż 20 słów. Jedna pozycja powinna dotyczyć tylko jednego zagadnienia $[18,26]$.

Pozycje kwestionariusza LittlEARS mają formę pytań. Większość uzupełniona jest przykładami, tak aby uniknąć błędów związanych z ich interpretacją. Uporządkowane są zgodnie $\mathrm{z}$ kolejnymi etapami rozwoju słuchowego dziecka. Większość z pierwszych 16 pytań kwestionariusza dotyczy zdolności do detekcji i dyskryminacji dźwięków. Pytania te obejmują rozwijające się w pierwszych miesiącach życia zachowania zwrotne, zorientowane i uważne, wywołane przez ludzki głos, muzykę czy zabawki wydające dźwięki. Kolejne pytania kwestionariusza 10, 12, 17-21 i 25-30 dotyczą głównie zdolności percepcyjnych związanych z identyfikacją dźwięków, tj. reakcji na imię, rozpoznawania wypowiedzi o zabarwieniu emocjonalnym, kojarzenia dźwięków z obiektami. Pytania 22-24 oraz 31-35 związane są z rozwojem rozumienia, manifestującym się umiejętnością wykonywania pojedynczych poleceń lub ich sekwencji, skupiania uwagi na słowie czytanym $[13,20]$.

Kolejnym etapem w procesie konstruowania nowego kwestionariusza jest określenie formatu odpowiedzi na przygotowane pozycje. Jednym $\mathrm{z}$ wykorzystywanych formatów odpowiedzi jest odpowiedź opisowa (kwestionariusze $\mathrm{z}$ otwartym formatem odpowiedzi). Badany ustosunkowuje się do pozycji kwestionariusza w formie opisowej. Pozycje mogą mieć również formę niedokończonych zdań, 
a zadaniem badanego jest ich rozwinięcie. Badanie kwestionariuszem $\mathrm{z}$ zamkniętym formatem odpowiedzi polega na wyborze przez badanego tej odpowiedzi, która najbardziej odpowiada jego ocenie. Popularnym sposobem odnoszenia się do pozycji kwestionariusza jest użycie skali wielokategorialnej. Badany wybiera jedną spośród kilku kategorii odpowiedzi (np. pięciu), które mogą zawierać następujące opcje: „Zdecydowanie zgadzam się”, „Raczej zgadzam się”, „Nie mam zdania”, „Raczej nie zgadzam się”, „Zdecydowanie nie zgadzam się”. Najprostszym formatem odpowiedzi kategorialnej jest format dychotomiczny (dwukategorialny) - jedna odpowiedź informuje o występowaniu danej cechy, druga o jej braku. Inną formą udzielania odpowiedzi jest rangowanie, czyli nadanie rangi poszczególnym stwierdzeniom kwestionariusza [26,27].

Autorzy kwestionariusza LittlEARS zastosowali dychotomiczny format odpowiedzi w celu uproszczenia procedury testowej i ograniczenia błędów związanych z subiektywną oceną częstości występowania obserwowanego zachowania słuchowego dziecka. Zgodnie $\mathrm{z}$ instrukcją rodzice udzielają odpowiedzi „tak” na dane pytanie, jeśli zaobserwowali określone w pytaniu zachowanie słuchowe przynajmniej raz, natomiast odpowiedzi „nie”, jeśli nie zaobserwowali określonego zachowania słuchowego lub nie są pewni, jak odpowiedzieć na dane pytanie $[13,20]$.

Niezwykle istotnym elementem jest standaryzacja, czyli określenie warunków, w jakich badanie będzie powadzone. Badanie powinno być poprzedzone: informacją dotyczącą celu badania, zwięzłą instrukcją, w jaki sposób wypełnić kwestionariusz. Powinno być prowadzone przez osoby odpowiednio przeszkolone, w warunkach podobnych dla każdego pacjenta. Badanie całej grupy pacjentów należy przeprowadzić w sposób określony przez autora kwestionariusza, np. w obecności osoby badającej, telefonicznie, listownie, $\mathrm{z}$ wykorzystaniem internetu (niektóre procedury testowe dopuszczają użycie kilku metod). Trzeba zadbać, aby zminimalizować czynniki mogące wpłynąć na odpowiedzi udzielane przez pacjenta, np. hałas, stres związany $\mathrm{z}$ pośpiechem. Procedura badania powinna być szczegółowo opisana, tak aby zapewnić jednakowe warunki badania przy każdorazowym użyciu kwestionariusza. Nieprzestrzeganie procedur testowych wpływa istotnie na wynik pomiaru i może prowadzić do błędnej interpretacji wyników i w konsekwencji do błędnej diagnozy [18,19].

Zgodnie $\mathrm{z}$ opisaną przez autorów procedurą badawczą, przygotowany w postaci papierowej kwestionariusz LittlEARS wypełniają rodzice badanego dziecka. Pierwsza strona kwestionariusza zawiera krótką informację dotyczącą celu badania i zwięzłą instrukcję jego wypełniania $[13,20]$. Specjalista prowadzący badanie nie powinien ingerować w proces jego wypełniania, powinien natomiast zadbać o opisane powyżej warunki przeprowadzenia badania oraz przestrzegać zasad prowadzenia badań z wykorzystaniem kwestionariuszy opisanych w wytycznych ITC dotyczących właściwego i etycznego stosowania testów [1].

\section{Walidacja kwestionariuszy}

Walidacja kwestionariuszy polega na zbadaniu docelowej grupy respondentów narzędziem przygotowanym wg powyższych zasad oraz na przeprowadzeniu oceny jakości kwestionariusza na podstawie analizy odpowiedzi uzyskanych dla poszczególnych jego pozycji. W badaniach tych konieczne jest uzyskanie świadomej zgody osoby wypełniającej kwestionariusz. Aby kwestionariusz mógł stać się wysokiej jakości narzędziem diagnostycznym, należy potwierdzić trafność i rzetelność pomiaru kwestionariuszem [3]. Odpowiednia trafność i rzetelność pomiaru wpływają na czułość metody oraz na sensowność interpretacji wyników badania.

Trafność pomiaru określa, czy kwestionariusz dostarcza informacji, które zamierzał uzyskać badacz. Innymi słowy, czy mierzy zakładaną przez badacza zmienną (wielkość). Wyróżnia się kilka rodzajów trafności: trafność teoretyczną, kryterialną i treściową. Trafność teoretyczna to zgodność pomiędzy wynikiem pomiaru a cechą, dla której pomiar został skonstruowany. Oszacowanie trafności teoretycznej możliwe jest poprzez korelację $\mathrm{z}$ wynikami innych testów, badanie wewnętrznej struktury testu, analizę różnic międzygrupowych, relację pomiędzy wynikiem i potencjalnie powiązanymi zmiennymi, dokonanie zmian w teście i ponowne zbadanie tej samej grupy, analizę procesu badania testem [27].

Badania wewnętrznej struktury testu dokonuje się poprzez ocenę wzajemnej korelacji poszczególnych pozycji testowych oraz ocenę ich mocy dyskryminacyjnej. O trafności pomiaru kwestionariuszem świadczy trafność poszczególnych pozycji testowych. Jeśli pozycje kwestionariusza są wzajemnie skorelowane, to dokonują pomiaru jednej cechy. Wzajemna korelacja pozycji testowych wiąże się z ich wysoką mocą dyskryminacyjną. Jeśli pozycja charakteryzuje się niską mocą dyskryminacyjną, to prawdopodobnie mierzy inną cechę niż pozostałe pozycje, jest nietrafna. Pozycje o niskiej mocy dyskryminacyjnej sa usuwane z kwestionariusza i dzięki temu uzyskuje się wysoką homogeniczność kwestionariusza. Wzajemna korelacja pozycji testowych i ich wysoka moc dyskryminacyjna świadczą o homogeniczności (zgodności wewnętrznej) kwestionariusza. Wysoka homogeniczność świadczy o trafności poszczególnych pozycji testowych i poprzez to o trafności pomiaru kwestionariuszem. Zadaniem badacza, w ocenie trafności teoretycznej oprócz badania struktury wewnętrznej testu, jest zgromadzenie innych dowodów wykazujących np. na korelację wyniku badanego testu z wynikami innych testów, różnice wyników w różnych grupach respondentów lub relację pomiędzy wynikiem i potencjalnie powiązanymi zmiennymi. Ocena trafności teoretycznej jest warunkiem koniecznym przy ocenie jakości narzędzia [26-28].

Trafność kryterialna to zgodność wyników uzyskanych $\mathrm{w}$ badaniu testem $\mathrm{z}$ kryterium zewnętrznym, np. $\mathrm{z}$ wynikiem innego badania. Trafność treściową natomiast bada się, oceniając stopień, w jakim treść pozycji kwestionariusza odpowiada definicji badanej cechy. Oceny trafności treściowej dokonuje się poprzez ocenę zgodności opinii sędziów kompetentnych - ekspertów w danej dziedzinie [27].

Rzetelność jest miarą dokładności pomiaru. Kwestionariusz dający rzetelny wynik to taki, który daje taki sam wynik przy kilkukrotnym badaniu tej samej osoby. Oszacowanie rzetelności pomiaru testem jest koniecznym elementem oceny jakości stosowanego narzędzia. Istnieje kilka metod 
szacowania rzetelności. Jedną z nich jest metoda powtarzanego pomiaru (test-retest), polegająca na dwukrotnym badaniu tych samych osób tym samym testem. Miarą rzetelności jest zbieżność wyników uzyskanych w dwóch badaniach. Metoda ta obarczona jest błędem związanym z efektem uczenia, ponadto jest czasochłonna ze względu na konieczność przeprowadzenia badania dwukrotnie. Metoda form równoległych polega na badaniu tej samej grupy dwoma niezależnymi narzędziami mierzącymi tę samą cechę. Rzetelność pomiaru oceniana jest na podstawie zbieżności wyników uzyskanych w obydwu testach.

Inną metodą pozwalającą na ocenę rzetelności na podstawie jednokrotnie przeprowadzonego badania jest metoda połówkowa. Szacowanie rzetelności polega na podzieleniu testu na dwie części, zbadanie całym testem grupy osób, a następnie skorelowanie wyników uzyskanych w jednej i drugiej części. W metodzie tej kluczowym elementem jest wybór pozycji, które znajdą się w poszczególnych połowach testu. Wybór ten jest utrudniony, jeśli poszczególne pozycje nie charakteryzują się podobnym wskaźnikiem trudności [19,26].

Ze względu na wady wyżej wymienionych metod, najczęściej stosowaną metodą oceny rzetelności testu jest badanie jego zgodności wewnętrznej. Założeniem metody jest podział testu składającego się z $n$ pozycji na $n$ części i badanie korelacji wyników uzyskanych dla każdej pozycji z wynikiem całego testu. Za najlepszy sposób szacowania rzetelności oparty na powyższym założeniu uważa się obecnie metodę zaproponowaną przez Cronbacha [29]. Wartość współczynnika alfa Cronbacha może przyjmować wartości z przedziału $(0 ; 1)$, wartość 0 oznacza, że pozycje kwestionariusza nie mierzą zakładanej cechy, a jedynie błąd, wartość 1 oznacza, że pozycje kwestionariusza mierzą tę samą cechę. Przyjmuje się, że uzyskanie wartości współczynnika alfa Cronbacha powyżej 0,7 jest satysfakcjonujące przy ocenie rzetelności testu [26,27,29].

Walidacja wersji oryginalnej kwestionariusza LittlEARS przeprowadzona została przez autorów kwestionariusza w grupie 218 dzieci o słuchu prawidłowym (Tsiakpini i wsp. 2004; Weichbold, Tsiakpini, Coninx i D'Haese 2005). Trafność badania została oceniona poprzez analizę struktury wewnętrznej kwestionariusza. Oceniano moc dyskryminacyjną poszczególnych pytań, analizowano rozkład współczynników trudności oraz badano korelację wyników dla poszczególnych pytań z wiekiem dziecka. Wysoka moc dyskryminacyjna większości pytań kwestionariusza (za wyjątkiem pytań $1-4,8$ i 14) została potwierdzona poprzez analizę skorygowanego współczynnika korelacji pozycja-skala oraz współczynnika korelacji punktowo-dwuseryjnej. Pytania od 1 do 4 zostały włączone do kwestionariusza z myślą o najmłodszych dzieciach. Dotyczą one zachowań słuchowych, które mogą być obserwowane nawet w pierwszych miesiącach życia dziecka, dlatego też słaba korelacja pozycja-skala nie jest dla tych pytań zaskoczeniem. Zasadność włączenia pytań nr 8 i 14, potwierdzają wartości innych wskaźników, takich jak współczynnik korelacji z wiekiem czy alfa Cronbacha. Wyniki tych analiz pozwoliły na dokonanie wyboru 35 pytań o największej mocy dyskryminacyjnej z przygotowanych na etapie tworzenia kwestionariusza 40 pytań $[13,15]$.
W celu przeprowadzenia analizy współczynnika trudności poszczególnych pytań kwestionariusza LittlEARS wyliczono średnie wartości odpowiedzi dla tych pytań. Dla kwestionariuszy z dwukategorialnym formatem odpowiedzi, gdzie 1 oznacza wystąpienie danej cechy, a 0 jej brak, średnia wartość odpowiedzi na dane pytanie może być rozpatrywana jako współczynnik trudności pytania. Wartość współczynnika trudności dla poszczególnych pytań kwestionariusza rośnie wraz z numerem pytania, co oznacza, że pytania uszeregowane są zgodnie $\mathrm{z}$ kolejnymi fazami rozwoju słuchowego dziecka $[13,15]$.

Ocenie poddana została korelacja uzyskanego wyniku $\mathrm{z}$ wiekiem dziecka. Uzyskana dodatnia korelacja $\mathrm{r}=0,91$ wskazuje na bardzo wysoką zależność liczby uzyskanych odpowiedzi „tak” od wieku dziecka (im starsze dziecko, tym bardziej prawdopodobne jest uzyskanie większej liczby punktów) i tym samym potwierdza, że kwestionariusz LittlEARS dokonuje oceny rozwoju słuchowego.

Rzetelność pomiaru kwestionariuszem LittlEARS oceniona została z wykorzystaniem metody połówkowej (split-half) oraz kryterium lambda Guttmana $(\lambda)$. Dla danych walidacyjnych kwestionariusza lambda Guttmana $\lambda=0,93$, zatem dokładność predykcji kwestionariusza może być uznana za bardzo wysoką. Wynik uzyskany w teście połówkowym (split-half) $\mathrm{r}=0,88$ wskazuje również na dużą dokładność pomiarową kwestionariusza. Ponadto autorzy dokonali oceny jednorodności kwestionariusza poprzez wyznaczenie współczynnika alfa Cronbacha ( $\alpha$ ). Dla danych walidacyjnych kwestionariusza uzyskano wynik $\alpha=0,96$. Przedstawione przez autorów wyniki analizy struktury wewnętrznej kwestionariusza oraz uzyskanie wysokiej korelacji wyników LittlEARS z wiekiem potwierdzają wysoką trafność i rzetelność pomiaru przeprowadzonego $\mathrm{z}$ jego użyciem $[13,15]$. Podobne wyniki uzyskano w procesie walidacji kwestionariusza LittlEARS w innych wersjach językowych, co czyni to narzędzie kulturowo uniwersalnym $[14,15,17]$.

Przeprowadzone badania walidacyjne pozwoliły również na wyznaczenie, na podstawie średnich wyników dzieci ze słuchem prawidłowym w poszczególnych przedziałach wiekowych (miesiącach życia), krzywej wartości oczekiwanej w zależności od wieku dziecka oraz krzywej wartości minimalnych [13-15,17]. Osiągnięcie przez dziecko wyniku zbliżonego do wartości oczekiwanej oznacza osiągnięcie poziomu rozwoju słuchowego odpowiedniego dla wieku. Wartość minimalna wskazuje na minimalny poziom rozwoju słuchowego, jaki powinno osiągnąć dziecko w danym wieku. Wartości minimalne oznaczają, że wyniki $95 \%$ dzieci z próby objętej walidacją znajdowały się powyżej tych wartości, a wartości poniżej tej granicy są mało prawdopodobne (<5\%) w danej grupie wiekowej. Osiągnięcie łącznego wyniku poniżej wartości minimalnej może wskazywać na nieprawidłowy rozwój słuchowy.

\section{Podsumowanie}

Wyniki walidacji kwestionariusza LittlEARS potwierdzają, że jest on narzędziem o wysokiej trafności i rzetelności pomiarowej. Stosowanie kwestionariuszy o wysokiej wartości diagnostycznej, tj. przygotowanych według zasad opisanych powyżej, gwarantuje wysoką jakość 
przeprowadzonego pomiaru. Brak dbałości o wypełnienie wszystkich elementów procedury przy przygotowywaniu narzędzi ankietowych może prowadzić do błędnego wnioskowania o uzyskanych wynikach badań.

Publikacja powstała $w$ związku z realizacja projektu pn. „Zintegrowany system narzędzi do diagnostyki i telerehabilitacji schorzeń narzadów zmystów (stuchu, wzroku, mowy, równowagi, smaku, powonienia)" INNOSENSE, wspólfinansowanego przez Narodowe Centrum Badań i Rozwoju w ramach Programu STRATEGMED.

Projekt został sfinansowany ze środków Narodowego Centrum Nauki przyznanych na podstawie decyzji numer DEC-2013/09/B/ ST7/04213.

\section{Piśmiennictwo:}

1. International Test Commission. International guidelines for test use. International Journal of Testing, 2001; 1: 93-114.

2. International Test Commission. International Test Commission guidelines for translating and adapting tests. 2016. Pobrane $\mathrm{z}$ : http://www.intestcom.org.

3. International Test Commission. International guidelines on quality control in scoring, test analysis, and reporting of test scores. 2012. Pobrane z: http://www.intestcom.org.

4. American Educational Research Association; American Psychological Assocation; National Council on Measurement in Education. Standards for Educational and Psychological Testing; American Educational Research Association; 2014.

5. Bond M, Mealing S, Anderson R, Elston J, Weiner G, Taylor R $i$ wsp. The effectiveness and cost-effectiveness of cochlear implants for severe to profound deafness in children and adults: a systematic review and economic model. Health Technol Assess, 2009; 13: 1-198.

6. Loeffler C, Aschendorff A, Burger T, Kroeger S, Laszig R, Arnd S. Quality of life measurements after cochlear implantation. The Open Otorhinolaryngology Journal, 2010; 4: 47-54.

7. Swan I, Guy F, Akeroyd M. Health-related quality of life before and after management in adults referred to otolaryngology: a prospective national study. Clin Otolaryngol, 2011; 37: $35-43$.

8. Obrycka A, Lorens A, Piotrowska A, Skarżyński H. Wykorzystanie kwestionariusza LittlEARS do oceny skuteczności interwencji związanej ze stosowaniem implantu ślimakowego u małych dzieci z głębokim niedosłuchem. Now Audiofonol, 2014; 3: 52-58.

9. May-Mederake B. Early intervention and assessment of speech and language development in young children with cochlear implants. Int J Pediatr Otorhinolaryngol, 2012; 76: 939-46.

10. Bagatto M, Moodie S, Malandrino A, Richert F, Clench D, Scollie S. The University of Western Ontario Pediatric Audiological Monitoring Protocol (UWO PedAMP). Trends Amplif, 2011; 15: 57-76.

11. Obrycka A, Lorens A, Piotrowska A, Skarżyński H. Ocena rozwoju słuchowego dzieci z głębokim niedosłuchem, którym wszczepiono implant ślimakowy we wczesnym dzieciństwie. Now Audiofonol, 2014; 3: 59-65.

12. National Institute for Health and Clinical Excellence. Guide to the methods of technology appraisal. NICE, London; 2014.
13. Weichbold V, Anderson I, D'Haese P. Validation of three adaptations of the Meaningful Auditory Integration Scale (MAIS) to German, English and Polish. Int J Audiol, 2004; 43: 156-61.

14. Obrycka A, Padilla J, Pankowska A, Lorens A, Skarżyński H. Production and evaluation of a Polish version of the LittlEars questionnaire for the assessment of auditory development in infants. Int J Pediatr Otorhinolaryngol, 2009; 73: 1035-42.

15. Coninx F, Weichbold V, Tsiakpini L, Autrique E, Bescond G, Tamas L i wsp. Validation of the LittlEARS ${ }^{\star}$ Auditory Questionnaire in children with normal hearing. Int J Pediatr Otorhinolaryngol, 2009; 73: 1761-68.

16. Obrycka A. Adaptacja i wykorzystanie kwestionariusza LittlEARS. Rozprawa doktorska; 2014.

17. García Negro A, Padilla García J, Sainz Quevedo M. Production and evaluation of a Spanish version of the LittlEARS Auditory Questionnaire for the assessment of auditory development in children. Int J Pediatr Otorhinolaryngol, 2016; 83: 99-103.

18. Foddy W. Constructing questions for interviews and questionnaires. Theory and practice in social research. Cambridge: Cambridge University Press; 1993.

19. Aranowska E. Pomiar ilościowy w psychologii. Warszawa: Wydawnictwo Naukowe SCHOLAR; 2005.

20. Tsiakpini L, Weichbold V, Kühn-Inacker H, Coninx F, D’Haese P, Almadin S. LittlEARS Auditory Questionnaire Manual. Innsbruck: MED-EL; 2004.

21. Northern J, Downs M. Hearing in children. Baltimore: Williams \& Wilkins; 1991.

22. De Casper A, Fifer W. Of human bonding: newborns prefer their mother's voice. Science, 1980; 208: 1174-76.

23. Cooper R, Aslin R. Preference for infant-directed speech in the first month after birth. Child Development, 1990; 61: 584-95.

24. Eimas P, Quinn P. Studies on the formation of perceptually based basic-level categories in young infants. Child Development, 1994; 65: 903-17.

25. Allum D. Cochlear implant rehabilitation in children and adults. London: Whurr Publishers; 1996.

26. Osterlind S. Constructing test items: multiple-choice, constructed-response, performance, and other formats. Boston, Dordrecht, London: Kluwer Academic Publishers; 2001.

27. Fronczyk K. Psychometria. Warszawa: Vizja Press \& IT; 2009.

28. Zumbo B, Chan E. Validity and Validation in Social, Behavioral, and Health Sciences. New York: Springer; 2015.

29. Cronbach I. Coefficient alpha and the internal structure of tests. Psychometrica, 1951; 16: 297-334. 